\title{
PIEREDZES MANTOJUMS: MEŽSAIMNIEKA ERNESTA BRIEŽA ATMIN,AS
}

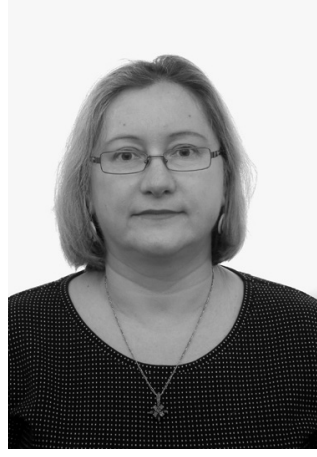

Ginta Elksne, Mg. sc. soc., Mg. sc. hum., Latvijas Universitātes Filozofijas un sociolog̣ijas institūta zinātniskā asistente, studē Rīgas Stradiṇa universitātes (RSU) Doktorantūras nodaḷas sociologijias studiju programmā. Latvijas Nacionālās mutvārdu vēstures projektā darbojas kopš 1994. gada. RSU aizstāvēts maǵistra darbs Denacionalizēta māja R̄̄gāa: iedzīvotāju biogrāfisko interviju analīze sociālo pārmainu kontekstā (2007). LU Humanitāro zinātṇu fakultātē aizstāvēts maǵistra darbs Agrīnās Haṇ, dinastijas vēsture un tās ietekme uz dinastiju vēstures pierakstīšanas tradīciju K̦īnā (2017). Zinātniskās pētniecības intereses saistìtas ar mutvārdu vēstures un biogrāfisko avotu analīzi, kvalitatīvo pētijjumu metodi sociologijāa dzīvesstāstu tekstu un citu dokumentāro avotu kontekstu analīzi, migrācijas un remigrācijas tēmu dzīvesstāstos, kā arī Senās Kīnas vēsturi un kultūru.
Raksturvārdi: mutvārdu vēsture, dzīvesstāsti, meža darbinieku pieredze, mežs kā vērtība.

Mutvārdu vēsture un dzīvesstāsti palīdz saprast citu cilvēku pieredzi, noskaidrot vēstures jautājumus, tuvina atškiirīgiem uzskatiem, tradīcijām, dzīvesveidam, kultūrai. Dz̄ivesstāstu intervijas pieder pie izziņas avotiem kvalitatīvajos pētījumos, kuros pētāmais cilvēks ir nevis pētniecības objekts, bet subjekts. Intervētājs mērķtiecīgi virzìtā sarunā rosina stāstu par dzīvi, kur atklājas ne tikai stāstītāja atspogulotie notikumi un to savstarpējā saistība, bet arī autora personības iezīmes, uzskati, saites - ǵimenē un plašākā sabiedrībā.

Filozofs, Latvijas Nacionālās mutvārdu vēstures projekta viens no dibinātājiem un ilggadējs zinātniskais vadītājs Augusts Milts ir rakstījis: "Katra cilvēka dzīvesstāstam ir neatkārtojama vērtība, jo tajā ir gan racionālas domas, gan izjūtu savdabība, gan iracionālie dzīves instinkti, daudzas grūti tveramas nianses. No katra mēs varam mācīties, ieskaitot arī pieredzi, kas izskan kā brīdinājums to neatkārtot."1 Mutvārdu vēstures avoti mums atklāj, kā cilvēks ir sapratis to, ko darījis, kam ticējis un ko joprojām domā, ka ir darījis. Tas mazāk stāsta par pašiem notikumiem, bet gan vairāk par šo notikumu nozīmi ${ }^{2}$.

Rakstā aplūkots mežsarga Ernesta Brieža (dzim. 1905) dzīvesstāsts. Intervija ieskaņota stāstītāja 90. dz̄ives gadā un ietver atmiņas no bērnības, atmiņas par tēvu - arī mežsargu, no kura stāstītājs ietekmējies profesijas izvēlē, 40 darba gadiem mežā, kā arī atziņas un pašvērtējumu. Dzīvesstāsts atklāj emocionālu tēlojumu, estētisko un ètisko vērtību nozīmi ar meža darbu saistītajā stāstītāja dz̄ivē, profesionālās pieredzes ietekmi uz personības izpausmēm. Kontekstam minēti piemēri no dažiem citiem meža darbinieku atmiņu ierakstiem, kas pieejami Nacionālās mutvārdu vēstures cilvēkarhīvā. Pieredze meža kopšanā un sargāšanā paver dziḷāku skatījumu uz cilvēka un dabas attiecību niansēm.

\footnotetext{
1 Milts 2001, 37.

2 Portelli 1998, 67.
} 
Ar Ernestu Briedi tikos pēc mežu vēstures pētnieces Aijas Zviedres ieteikuma. Pati nākusi no mežkopju dzimtas, arī savu dzīvi veltījusi mežsaimniecības profesionālās vēstures un individuālo meža darbinieku atmiņu apzināšanai. Viņa pazina daudz vecākās paaudzes meža sargu un kopēju, kuru dzīvesstāstu vajadzētu uzklausīt. Viens no galvenajiem iemesliem - šai profesijai vēsturiski notikusi stingra atlase. Ne cilvēks izvēlējās mežu, bet mežs - cilvēku, kurš grib un var tam kalpot, neskatoties uz darba smagumu un prasībām, ko dažādos laikos uzlika dažādi mežsaimniecības pārraugi un īpašnieki. Nav nejaušǐba, ka tēviem līdzās auga pēcnācēji - mežkopju dinastijas turpinātāji. Intervijā mans uzdevums bija noskaidrot, izprast, kā atmiņās par dzīves gājumu atklāsies stāstītāja raksturs un personības īpašības, kas veidojušas tik dziļu un pamatīgu piesaisti savai profesijai, kā attīstījušās attiecības starp cilvēku un mežu dabas vidi un kā tās ietekmējušas attiecības ar citiem cilvēkiem. Sabiedrībā pieņemts uzskats, ka meža profesija saistās ar romantiku un cildenām rakstura īpašībām, noslieci uz apceri un gluži vai šamaniskām spējām nostiprināt saikni ar Universu. No otras puses - pašlaik izplatītais skatījums uz mežu galvenokārt kā materiālo vērtību un peḷnas avotu disonē ar rūpīga saimnieka attieksmi, ko iemieso arī aplūkojamais profesionālā mežkopja stāsts. Tas ir vēl viens motīvs, kas liek ieklausīities amata pieredzē un vērtēt, kā saimnieciska attieksme atšķiras no daudzu īpašnieku attieksmes, kuri, gan ieguvuši mežu īpašumā, stāv tālu no tā, nespējot saskatīt meža kā dabas resursa skaistumu un ilglaicīgo vērtību.

Intervija ar Ernestu Briedi ierakstīta audiolentē 1995. gadā Olainē. Tagad, atgriežoties intervijas situācijā un vērtējot uzklausīto atmiņu stāstu, pavēršu skatu uz reāla cilvēka mūža pieredzi un veidu, kā cilvēks pats to saprot, vērtē un pasniedz. Stimuls intervijai iepazīt personību, kurš audzis un mūžu nostrādājis mežā un ir mežkopju dinastijas pārstāvis. Sekojot stāstam, var vērot attēloto notikumu iespaidu un to, kā stāstītājs pats tiem atrod vietu un nozīmi savā dzīvē. Raksta mērkisis ir izsekot meža darbinieka profesionālās pieredzes un personības savstarpējām attiecībām, kas atklājas dzīvesstāstā.

\section{Bērnība un skolas gadi}

Ernests Briedis dzimis 1905. gadā Cēsu apriņķa Rankas pagastā, un šajā apkaimē pagājis gandrīz viss viņa mūžs. Izglītību ieguvis Jaunpiebalgas draudzes skolā, pēc tam beidzis Rīgas 2. Valsts vidusskolu un Raiskuma mežsaimniecības skolu.

E. Brieža tēvs bijis mežsargs, kurš sācis strādāt, kad vēl baronu laiki bij .. viņš jau bija sācis pie barona. Mežsaimnieka profesionālā ceḷa izvēelē dēlu ietekmējis arī sākotnēji visai romantiskais priekšstats par tēva darba lauku: Esmu mežsarga dēls. Un, kā jau dēlam, mežs likās kā tāda teiksmaina valstība. Tētis pārnāca mājās un jautāja - zini, ko es redzejju? Redzēju stirniņu. Lielo stirnu ar mazo stirninu, abas divas tā smuki staigāja èzdamas. Un man arī tā gribējās redzēt visu to! Tēva stāsti par mežu rosina iztēli: Viņš daudz ko stāstīja, $k \bar{a}$ mežā izskatās. Un man kā mazam puikam tas viss tāds likās tāds brīnišķīgi skaists, ka nu tikai!

Ernests Briedis savu bērnību tēlo kā lauku zēna ikdienu. Iztikšana nav bijusi viegla, ǵimenē auguši septiņi bērni. Kad gājis pamatskolā, abi celgaliṇi bija salāpīti un pastalas kājās. Bet mācījāmies jau, kā varējām. Lai gan stāstītājs kritiski norāda, ka mēs jau bijām toreiz godīgi bērni, nebijām jau tādi kā tagad, palaidñi, tomēr stāstā netrūkst arī bērnu dienu nerātnību. Stāstītājs atminas gan epizodi, kad gandrīz noslīcis dzirnavu dīḳ̂, gan piedzīvotās briesmas, vizinoties uz ledus gabala pa Gauju.

Attiecības gímenē raksturo stāstītāja sniegtais vecāku raksturojums: Mamma bija ìsta latviete, čakla sieva, bērnus audzināja nopietni, rūpīgi. Par pēršanu jau ne tik daudz, bet galvenais labām mācībām un stingrību. Tā kā es jau nekad pērts netiku, bet audzināja stingri un kārtīgi. Tète... Tēte jau bija mežsargs, tāpat patika iemest vairāk drusku. Bet kurš mežsargs tad gan nedzer, jāsaka. Mazā piebilde par to, kas, iespējams, tomēr nebija tik labi, liecina par solidaritāti gan ǵimenes lokā, gan pret citiem mežsargiem kā kopību.

Stāstītājs atklāj dramatisku epizodi, kad viņš, būdams pavisam mazs zēns, smagi saaukstējies un saslimis; nav varējis staigāt. Vienu laiku gulēju vāgìišos un skatījos zvaigznēs. Vēlāk nejauši noklausījies sarunu; māte 
stāstījusi radiem, ka lūgusi Dievu - ja nu netiekot vesels, tad labāk lai nomirstot, tik nespēcīgs esot bijis. Pamazām atveseḷojies, tomēr bērnībā pārciestā slimība pavērusi iespēju izglītoties: Mamma teica tā - Ernīt, tu tāds pašvaks veselībā vēl no jaunības dienām biji, sūtīsim kā vienīgo uz vidusskolu. Nu, un tā es tiku Rīgā!

Pēc dienesta armijā Briedis uzsācis mācības Raiskuma mežsaimniecības skolā. Viṇš atminas labus skolotājus (Danenbergs, Zihmanis, Gulbis). Kā teicama pieredze minēti praktiskie darbi, kad katram audzēknim ticis iedalīts zemes gabals, kas pašam jāapkopj: Katram bija ierādìts tāds zemes gabaliňš, kas bija jāuzrijolè ${ }^{3}$, jāapsēj ar priedèm un ar eglītēm, kāda nu kurā vieta tur bija ierādìta. Un tad pašam tas bija jāaudzē, viss priekš meža, kas vajadzīgs. Tā bija vērtīga skola. Skolotāji bija labi un mācīja labi.

\section{Pašam sava apgaita}

Skolas beigšanas laiks sakrita ar ekonomiskās krīzes gadiem, kad jāpieṇem jebkāds darbs: Tas bij' tas bezdarbnieku laiks, uzreiz vietu nevarēja dabūt. Bet nebija jau ilgi. Es pa to laiku gāju uz Rankas papes fabrīku pien,emt materiālus, tanī laikā kaut ko nopelnīt, jo nevar tak sēdèt mājās uz tētes rēḳina lai. Un tad 32. gad̄̄ piedāvāja mežsarga-virsmežsarga vietu, nu un es jau to ar steigu pieñèmu. ${ }^{4}$

Darbu uzsāk ar stingru apņemšanos: $T \bar{a}$ kā es biju mežsarga dēls, es biju apñēmies, ka es kārtīgi savu apgaitu uzturēšu un rūpēšs ne tikai par mežu, lai mežs būtu apstādìts, apsēts un apkopts, bet arī lai zvēriņi būtu apgādāti.

3 Rijolēt - art, apstrādāt augsni dziḷāk par aramkārtu.

4 "Iecelšanas, pārcelšanas, atvaliināšanas mežu departamentā. Ernests Briedis iecelts par mežs. v. izp. uz br. līg. Cēsu v-bas 3. apg. ar algu 75 Ls mēnesī bez kādām citām piemaksām naudā, ar 1. aprīli." (Meža Dzīve, 01.10.1932., 86) "Personālās ziṇas mežu resorā. Pārskaitīti citā amatā. Cēsu v-bas 3. apg. mežs. Ernests Briedis par virsmežs. 1. iec. mežniecībā un par mežsargu minētā apgaitā, skaitot pārskaitī̌sanu un izdienu min. pakāpē ar š. g. 1. febr." (Meža Dzìve, 01.02.1933., 90)
Lai nebūtu tā, ka tētis atnāk mājās un sakavot, stirnina bija nošauta.

Stāstîtājs piešķir nozīmi dabas estētikai un arī sava darba estētiskam vērtējumam. Viņš priecājas, ka apgaita bijusi smukā vietā, un raksturo savus dienas darbus: Strādāju arī cìtīgi. Kopu mežu. Katru meža kvartālu izstaigāju. Sausos un gāztos visus uznumuroju, ierakstīju tādā dastošanas lapiṇa, tad tos novērtēja, iesniedzu mežniecībā, un mežzinis tad pēc tam pārdeva vietējiem iedzīvotājiem. Visu izstaigāju, sanumuroju, un mežs bija dažos pāris gados priekšzīmīgā kārtībā.

Ernests Briedis atminas, ka tad, kad sācis strādāt mežniecībā, trūcis stādāmā materiāla. Izmantojot Raiskuma meža skolā iegūtās zināšanas, Ernests Briedis kopā ar strādniekiem ierīkojis stādaudzētavu - apstrādājuši zemi, ierīkojuši dobes, sasējuši sēklas un paši izaudzējuši stādāmo materiālu. Apstādījuši savu un arī kaimiņu mežsarga apgaitu, visas tukšās vietas jeb lauces ${ }^{5}$.

Mežsargam darba mežā netrūkst, ja vēlas uzturēt labi koptu mežu. Padarītais sniedz gandarījumu. Man patīk priežu sili. Ir jau egles arī loti skaistas, bet tie meži ir tādi kā drūmāki. Tumši tādi. Un pie tam egles aug tur, kur labāka zeme, tur apakšà tāds mitrs kādreiz un tāds piegružots. Bet, ieejot silā vai priedulājā, - saulīte spīd!

Prieks par mežu ir saistīts arī ar paša darbu: Ja tu esi mežu izkopis, ja tev nav tādu koku lüžņu zemē, tad tak ir brīnišk̦igigi! Un jaunaudzìtes, kuras tu esi iestādījis, tās aug tik smuki, priežu dzinumi nāk uz augšu, cik svaigi un smuki - prieks redzèt, prieks par savu darbu. Jebkuros laikos varot uzturēt labi koptu mežu, ja tikai grib, bet tā gribēšana laikam nav.

\section{Mežs, dzīve un romantika}

Kārtīgai strādāšanai ir arī ēnas puses. Stāstītājs atzīst, ka nav bijis tas labākais palīgs sievai mājas darbos, jo daudz laika aizñēmuši darbi mežā: Vienā ziṇā gan es biju neakurāts. Sieviñai palīgā gandrīz nekad nevienos darbos netiku. Tikai pa mežu. Nu, bet patiesībā, lai

5 Lauce - ar mežu neapklāta zeme (meža zemē), kas neatbilst deguma, iznīkušas audzes, vējgāzes, izcirtuma un rekultivētās zemes pazīmēm. 
visu to izstaigātu un pēc tam atkal pārbaudītu, vai nav kāds cirtējs kaut ko pārcirties, tur darba bija diezgan.

Mežsarga ikdiena nav tik romantiska, kā tas var šķist jūsmīgam vērotājam no malas, - svaigs gaiss, skaisti koki, dzied putni. Pats gaiss jau ir svaigs, bet kādi citi apstākl̦i ir? Pusdienas tu mājās nedabū nekad siltas ēst, ja tu kārtīgs mežsargs esi. Uzkod to sauso maizìti vēl, vai nu pañem kādu tēju lìdz vai ko un dzīvo. Savukārt ziemā, kad notiek lielie mežu ciršanas darbi, mežsargam jābūt klāt un jāuzņem tie koki. Rokas ir nosalušas tā, ka tu nevari vairs pakustināt. Cimdi ir, bet tas neko nedod. Ozons jau ir, tā jau tur ir daudz, ko ostît. Bet tie citi apstākḷi nemaz tik labi nav. Un vèl tie paši malumednieki.

Savukārt ilggadēji meža darbinieki Juris un Gunta Lapkaši ${ }^{6}$ intervijā atklāja epizodi par nopietnu kaitējumu mežkopja veselībai, ko izraisījis inficētas ērces kodums. Tā kā tolaik darbā nav bijusi noorganizēta savlaicīga vakcinācija, meža darbinieka karjerai izraisīto komplikāciju dēḷ nācies pielikt punktu.

Tomēr romantikas netrūkst ne Ernesta Brieža dzīvē, ne atmiņu stāstā. Ja visa dzīve noris mežā, tad mežā notiek arī svarīgi dzīves notikumi. Gluži kā pasakā jaunais mežsargs mežā atrod savu nākamo sievu: Vienreiz, ejot pa savu mežu, nāk viens sievišķit's un dzen savus lopus pa mežu cauri. Suns arī vingai klāt. Es uzreiz - suņi mežā nedrīkst atrasties! Suṇi tak med̄̄ zaķus un tā tālāk. A š̉ tā lielìgimans sunīt's nemaz nav mežā, viņš, kā redzat, ir uz cel̦a, un viņ̌ jūsu zaķus neker, bet man palìdz govis ganīt! Izrādījās, ka viniem bija netālu tāda plaviņa, un šs dzen tās govis uz to ganību. Un nu iepatikās tā meitinga ar to smuko valodinu, ar aso.

Tā vārds pa vārdam, un tiek norunātas nākamās satikšanās, gājām uz Gaujmalu, tur ievas ziedēja, smaržoja smuki. Randiņu laikā jaunie l̦audis izbauda romantiku, un izrādās, ka jaunā sieva ir ne vien skaista un gudra, bet arī labi šauj ar revolveri. Tā reiz, sēžot zem ievas, stāstītājs piedāvā iecerētajai pamēǵināt šaut mērḳi ar līdzi paņemto revolveri. Domājis, ka sievietei jau nu nekas nesanāks. Tēmēe, tēmē lielu laiku. Es domāju, nešaus jau

6 NMV-4689. laikam, nemāk. Beigās-pliukt! A bet ietrāpīts tajā papīrā! Tad bij' atkal lustes visiem, ka tik labs šầejss mana sieva ir.

Kad viņi 1934. gada Ziemassvētkos Cēsu baznīcā salaulājas, jaunais vīrs var būt apmierināts, jo laulāto vecuma starpība atbilst viņa priekšstatam: Sieva ir pieci gadi jaunāka par mani, tas taisni tā, kā vajag, sievietēm jau vajag būt jaunākām. Sievai paticis darboties pašdarbībā, bet drīz mājas rūpes prasījušas savu un tam vairs nav atlicis laika. Atklājas atšķirības raksturos un attieksmē pret sabiedrisko dz̄ivi: Es personīgi sabiedriskā dzīvē nepiedalïjos. Nebija laika, un man patika mežs. Ja man bij' brīvs laiks, tad es aizgāju uz mežu labāk. Es jau biju tam mežam nodevies un tai mājas dzīvei mazāk. Jāatzīstas, kas ir, tas ir.

Stāstītāja repertuārā ir vairāki stāsti, kuros viņš, vēlēdamies izcelties un sevi izrādīt sievas un bērnu priekšā, tomēr rezultātā nonāk neveiklā situācijā. Pats stāstītājs šo stāstus atstāsta ar humoru, beigās vēl pievienojot morāli, ka nav labi lielīties, pirms darbs padarīts.

Reiz gadījies, ka netālu no mājas jaunaudzîtē iecilpo zakisis. Stāstîtājs nolemj sagādāt pusdienām cepeti un pie reizes pasauc sievu nāc, paskaties, kā zaķus šauj! Tomēr neizdodas tieši trāpīt. Zaḳis parādās tādā leṇķ̄ī ka, ja tu gribi šaut, tad tev jāšauj tieši dibena ciskās .. vienkārš̌i dibenā jāšauj. Nu, un ko tur darīs citu? Esi sievu aicinājis - jāšauj! Izšauju - es nu redzu, spalvas vien pajūk, tās skrotis, kas gar malām iet, tās nodzen spalvas gar tiem sāniem. Zaķis gan paliek bišķi lēnāks, bet aiziet!. Zaki neizdodas nošaut ne ar otro, ne pat ar ceturto šāvienu. Nu tak pēdèjā patrona, piektā, bija, to ielādēju, izšauju, nu, un ta zaķis ar teica - nu labi, pietiks - apgūlās! Ar pieciem šāvieniem, pakal skriedams pie tam! Nu un nesu to zaķi laukā tagad, sieva sakanu es gan redzēju, kā zaķus šauj! Situācija attēlota kā spēle, kur arī zaķim piešķirta sava loma, pat ar tekstu. Mednieka attieksme pret medījumu ir racionāla, tomēr tas neliedz uztvert to kā sacensību partneri.

Citā reizē aicinājis sievu palīgā, lai izdzītu lapsu no meža. Lapsa ilgi nerādās, un mednieks uzliek plinti plecā, domādams, ka tā jau aizgājusi uz Lapsu kalniņa pusi. Bet pēkšņi lapsa uzrodas. Kamēr mednieks ķer bisi un notēmē - tā jau ir projām. Arī šajā epizodē 
stāstītāja sieva atklājas kā racionāla situācijas vērtētāja: Un tad ši nosvētīja mani - vai tad tu nezini, kā medniekam jādara, jāstāv, kamēr dzinējs iznāk. Ja es būtu stāvējis un gaidījis ar plinti uz rokas, lapsa bija mana.

Stāstītājam ir raksturīgs paškritisks skats un spēja atklāt sevi neveiksmīgās, neveiklās situācijās. Bieži kā "veselais saprāts" stāstā parādās sieva, kas ar prātīgu teicienu rezumē situāciju. Morāle ir skaidra - nevajag lielīties!

\section{Mednieku stāsti}

Stāsti par medībām, ne tikai privātām, bet arī organizētām mežsargu atmiņās ieņem ievērojamu vietu. Medību uzraudzība ir viens no mežsarga pienākumiem un Briedim arī personīga aizraušanās. Kamēr mežsargs biji, tad bija obligāti jābūt, ja tavā apgaitā bija medības. Bet lielākoties man jau arī interesēja medības, tad es parasti piedalījos. Tas ir tāds sports. Ja nāk tas zaķis tā kūleniem vien, kūleñiem vien, un tad tev vajag notèmèt un - lai viņš krīt! Zak,im vēl tā, bet sevišk,i, ja lapsin,a $n \bar{a} k-o i !$

Nacionālās mutvārdu vēstures krājumā ir arī stāsts par īpašām medībām ${ }^{7}$, kas Latvijā pēc kara tikušas sarīkotas maršalam Vasilijam Čuikovam. Tajā laikā Latvijā pastāvēja tāda pusmilitāra organizācija - Civilā aizsardzība. Un š̄is organizācijas vadība bija uzticēta maršalam Čuikovam. Tā kā viña amata pienākumos ietilpa arī šo organizāciju pārbaudī̌sana. Maršals Čuikovs, büdams mednieks, bieži savus inspekciju braucienus savienoja ar medībām. Jelgavas mežrūpniecības direktors sañēma no savas ministrijas ziņu, ka medību nolūkos mežrūpniecību apmeklēs mar$\check{s}$ als Čuikovs, un direktoram bija jānoorganizē medības maršalam ar vinga svītu. Maršals no Maskavas Rīgā ieradās ar speciālu vilcienu. Šajā speciālajā vilcienā bija tikai divi vago$n i$ - viens salonvagons, kurā brauca maršals ar pavadoniem, un otrs vagons bija platforma, ar kuru tika atvesta lìdz Rìgai maršala personīgā čaika. ${ }^{8}$

Ieradies Rīgā, maršals ar šo automašīnu atbraucis uz jau iepriekš noorganizēto medību vietu Jelgavas mežrūpniecības Elejas mežniecībā. Lai arī maršals bijis geērbies vienkārši, aizsargkrāsas frencī, bez ordeñiem un zvaigznēm, viņam visur sekojis adjutants, kurš nesis maršala ieročus. Nesa tādēl, ka šiem ieročiem nebija plecu siksnas, jo tās traucēja mērksēšanā, tādēl ieroči tika nesti rokā. Ieroči bija divi. Viena bija ložu bise priekš lielākiem dz̄̄vniekiem un šķeltnadžiem, bet otra bija medību bise, divstobrene, kura domāta sīkākiem medījumiem. Un tā nu medībās maršala aizmugurē vienmēer stāvēja adjutants ar šaušanai sagatavotiem ieročiem un vērīgi sekoja - tiklìdz kāds zvērs tuvojās mednieku līnijai, tā tika pasniegts vajadzīgais ierocis - tā kā dakterim pie operāciju galda.

Pusdienlaikā uzradies armijas ekonomiskā veikala pikaps ar veikala darbiniekiem, kuri sagādājuši medniekiem vajadzīgās uzkodas un dzērienus. Dzinējiem sagatavotajā devā atradies baltmaizes kukulītis, divas mednieku desas un degvīns Kristāldzidrais. Mednieki novietojušies atsevišksi - tur bija visas iespējamās gastronomijas uzkodas un delikateses, ko varēja sniegt armijas ekonomiskais veikals. Pusdienu noslēgumā veikala pārstāvis piegājis pie maršala, kurš vienkārši ar savu parakstu akceptējis visus izdevumus. Kā atcerējies klātesošais liecinieks, tajā reizē mēs sapratām, ka maršals jau dzīvo komunismā, jo viņam nauda nebija vajadzigga.

Stāsts, gluži tāpat kā to izstāsta Jēkabs Vilīitis, ir ne reizi vien pārstāstīts un ceḷojumā no mutes mutē ieguvis jaunas detal̨as. Meža darbinieki jau bija pieraduši pie savu "kungu" anekdotiskajiem medību paradumiem. Tomēr Ernests Briedis savā stāstā lielāku uzmanību pievērsa nelegālajiem medniekiem un to nodarītajam postam.
7 Epizode no 1995. gada intervijas ar mežsargu Jēkabu Vilīti (NMV-226) (dzimis 1925), kurā viņš atstāsta sava drauga, meža darbinieka Aleksandra Beķera pieredzēto gadījumu.
8 Padomju Savienībā augstu amatpersonu iecienīts limuzīns, Gorkijas automobiḷu rūpnīcas (GAZ) ražojums pēc ārzemju paraugiem. 


\section{Mežsargs un malumednieki}

Stāstu par malumedniekiem Ernests Briedis iesāk ar īsu ievadu, kurā paskaidro, kāpēc bijis tik nesaudzīgs. Viṇš bērnībā esot apṇēmies rūpēties par meža zvēriem un vēlāk sapratis, ka malumednieks kā likuma pārkāpējs ir bīstams, jo krīzes situācijā gatavs apdraudēt arī mežsargu: Ar malumednieku ir grūti rēḳināties. Latvijas laikā vairākās vietās dzirdēju, kur mežsargs no malumedniekiem nošauts. Ja vinni satiekas viens pret vienu, viňš jau tevi nežēlo. Bet tas jau nenozìmē, ka es neiešu karot ar malumedniekiem!

Katrs stāsts tiek izstāstīts secīgās epizodēs, kur svarīgas ir arī detaļas. Tâ, piem., pirmajā stāstā mežsargs satiek mežā kādu vecu sieviņu, kura, nākdama pretējā virzienā, jautā pēc ceḷa uz Cēsīm. Kad gabalinu tālāk stāstītājs sastop vīrieti ar bisi kaklā, vinam top skaidrs, ka tas ir malumednieks un iepriekš satiktā sievina bijusi š̄ malumednieka dzinējs. Es tagad ar pielieku vēl lielāku soli, sameklēju revolveri un uzsaucu: stāt, rokas augšā Es pārbaudī̌̌u jūs! Ko jūs domājat, ko šis dara? Nemet vis rokas augšă. Atrāva savu pusprakīiti val̦ā, nonem plinti no kakla nost. Es jau biju dzirdējis, ka malumednieki nošauj arī mežsargu. Man bij' jāizlemj, ko nu darìt. Vai nu pielūgties vinnu, lai viņš iet laimīgs, vai riskēt! Izmantojot fizisku spēku, malumednieks tiek sagūstîts. Pa cel̦am uz Cēsu policiju malumednieks izbēg, sākas pakaḷdzišanās, bet jaunais mežsargs izrādās ātrāks.

Stāstā par malumednieku ķeršanu ir gan risks, kad mežsargu glābj tikai veiklība, jo malumednieks ir gatavs šaut, taču nepagūst salikt kopā ieroci, ko izjauktu noslēpis zem apmetņa; ir pakaļdzī̌̌anās epizodes un joki, piem., kad "brašajam" malumedniekam no pārdzīvojumiem bikses pilnas. Malumedniekam tiek atņemta bise, piespriests 30 latu sods, bet mežsargam - prēmija. Žurnāls Meža Dzīve publicē mežsarga foto ar malumedniekam atn,emto bisi. ${ }^{9}$

Citā reizē malumednieks tiek izskaitḷots pēc atstātām pēdām - viņšs uz ceḷa atstājis raksturīgu zābaka zoles nospiedumu. Sekojot pēdām un izskaitḷojot, no kurām mājām varētu

9 Meža Dzīve, 01.06.1936., 130. būt nākuši likumpārkāpēji, arī vinuus izdodas nokert.

Vēl vienā atminuu epizodē tiek stāstīts par malumednieka uzbrukumu kolēǵim, ar kuru mežā bijusi norunāta tikšanās. Kolẹgis atnāk vaigs pušu, asiņains. Esot uzgājis virsū kādam malumedniekam, bet tas bijis veiklāks un iesitis vingam ar plinti pa galvu. Labi, ka dzīvs palicis. Ja būtu pa deniñiem, bütu beigts bijis, bet tā-vaiga kauls gluži pušu nebija, bet brūce dikti liela, asinaina un zilums - nu riebīgs skats pavisam. Ko tad nu darīsim tagad? Neiesim tak palaisties atkal malumedniekam! Iesim pa pēdām, kersim pa pēdām rokā.

Par malumednieku noḳeršanu mežsargam pienākusies prēmija, tomēr tā nebija galvenais malumednieku k̦eršanas iemesls: Tur jau liela prēmija nebija, bet tikai tā, lai tos malumedniekus apkarotu, lai tām stirniñām būtu drošăka dzīve. Mežsarga uzcītība esot atmaksājusies arī tādējādi, ka viņa apgaitā malumednieki mazāk darbojušies. Vispār nejuta, ka tuvumā kaut kas notiktu. Jo viņi jau juta, ka tas virsmežsargs ir dulls, un tas mežsargus arī sakurina, un viņi kilometriem tālu skrien pakal medniecinam.

\section{Mežs kā patvērums}

Pēckara gados arī mežziṇa Brieža apgaitā slēpušies mežabrāḷ. Tieša saskare ar viṇiem nav iznākusi, lai gan Briedis zinājis, kur bunkuri atrodas. Bija mežā bunkuri. Viens bij' labi tālu, tādās vecās pozīcijās. Tur bija smiltin,a, šur tur pagrūž no tā bunkura laukā un nemaz neredz, ka tāds izbūvēts ir. Tikai varēja redzèt, kur cilvēki ir staigājuši, pēdas paliek, ja vairāk reizes iet. Nu un otrs bija turpat netālu no mūsmājām, tādā jaunaudzītē ierīkots, neliels bunkurin̦š.

Mežsargus ḷoti tramdījušas varas iestādes, taujājušas par mežabrāḷu slēpšanās vietām. Atlicis vien samelot, ka viña mežā bunkuru nav. Bet tas bija drausmīgi tomēr. Tu labi zini, ka tev mežā ir bunkuri. Aizsauc uz Cēsìm tie politruki-nu, Briedi, jūs kā meža darbinieks, vai zināt, kur ir bunkuri? Uzrādiet! - "Manā mežā nekādu bunkuru nav. Man neviena paša bunkura nav." - "Nu, smotri!"”10

\footnotetext{
${ }^{10} \mathrm{Nu}$, skaties! - krievu val.
} 
Ar cilvēkiem, kas slēpjas bunkuros, Briedis tiešā saskarē nenonāk. Tomēr viņš arī piever acis uz to, ja notiek nesaskanotas medības - cilvēkiem, dzīvojot mežā, nepieciešama pārtika. Ja nu viņi medīja, tad tai reizēes neskatījos, jo viņiem arī ēst gribējās. Vienu no mežabrāḷiem gan pazinis personīgi, tas bijis jauns mežsargs, kurš slēpies, kāda radinieka pierunāts: Tāds jauns mežsargs, Antons vārdā. Diemžēl šī epizode beigusies bēdīgi: Tur nāca viens jauns mežsargs, un vai nu tas bija izstāstījis, vai nu kāds cits, kas to nu zina. Vienā jaukā dienā atbrauca vesela karavīru brigāde, aplenca bunkuru. Teica, lai lien laukā, bet neviens nelīda. Tad ar rokas granātām sāka mest. Un to vienu beigtu atrada, un tas mans Antonu Jānis, tas mežsargs, viņš bija gan ievainots, bet dzīvs. Ielika Cēsu slimnīcā. Bet šis laikam vai nu nervozédams, vai kā nu tur bija... bēdzis it kā projām un tika nošauts.

Latvijas meži pēckara gados daudziem cilvēkiem deva fizisku patvērumu. Kā norāda antropoloǵe Vieda Skultāne, - saskatīt mežā patvērumu ir sena tradīcija Latvijā; tā ne tikai saistās ar vēsturiskām asociācijām par vajāto slēpšanos mežā, bet arī sakṇojas folkloras, literatūras un cilvēku ikdienas uztverē par mežu kā pastorālu idilli. ${ }^{11}$

Mežsargam un dundadznieku izloksnes aizstāvim Vilnim Mitleram ${ }^{12}$ mežs ir bijis patvēruma devējs gan valodai (Dundagas izloksnei), gan cilvēkiem: Man bija tā laime vai nelaime, ka es visu savu dzīvi nodzīvoju mežā, nostrādāju. Redziet, mežs bija tā vieta, kur krievu laikos varēja strādāt citur nederīgie. Tas ir, legionāri, budži, teiksim, un visi šitie... padibenes. Un viņi varēja strādāt mežāa. Nu un par cik vini visi lielāko dal̦ bija iedzimtie, tad mums mežā tā izloksne saglabājās. Mēs jau nerunājām kaut kādā citādā, pareizā valodā, bet izloksnē. Nu un tā es kaut ko vēl atceros. Mežs V. Mitlera stāstā atklājas kā cita pasaule, kur vismaz uz kādu brīdi patverties citādajam vai vajātajam.

11 Skultans 2005, 83.

12 Dundžiņ valod, Kubalu skola - muzejs Mežsausterē. Intervija ar Vilni Mitleru (dz. 1930, intervēts 2011) (NMV-3167).

\section{Mežs kā brīnums, kā teiksmaina vieta}

Socioloğe Baiba Bela uzsver, ka "dzīvē pieredzētie spilgtie notikumi paši par sevi vien nav iemesls, lai rastos labs dzivesstāsts", nepieciešama arī laba valodas izjūta un valodas izteiksmes līdzekḷu pārvaldīšana, kā arī laba stāsta kompozīcijas izjūta. ${ }^{13}$ Mežsarga E. Brieža stāstam ir raksturīga sava specifiska tēlainība. Viṇš runā par mežu niansēti, attēlo mirkḷa noskaņas, spēj iedzīvoties kokos un zvēros, reizēm tos uzrunājot deminutīvos. Ar sev piemītošo tēlainību viņš personificē velna tēlu un lauj tam darboties savas iztēles atmiņās. Velnam ir ierādīta pretspēka loma. Saucot pamazināmā vārdā - velnīt's -, tiek atñemts tam spēks, pieškirta nedaudz ironiska nozīme. No biedējoša tas kḷūst vairāk līdzīgs Latgales keramiḳu attēlotajiem bezbēdīgajiem blēndariem. Tomēr velnìt's kā spilgts tēls apzīmē to neizskaidrojamo, vareno, biedējošo, ar ko nācies saskarties mežā.

Pirmo reizi velna tēls parādās bērnības atmiṇu epizodēs. Stāstītājs, vēl bērns būdams, velnu vainojis skaistu koku izpostīšanā un piedraudējis ar atmaksu. Kā sekas stāstā atklājas dažādi notikumi, kas cilvēkam norāda vina paša īsto vietu dabas varenības priekšā. Es jau bērnības dienās biju paredzējis, kad es to mežu saudzēšu. Un lai tas velns, kas tos kokus man gāž un lauž... kad es pieaugšu es teicu brālim - es vinu uz elli aiztriekšu! Velns gāza kokus? - Bet kas ta' cits? Smuks, liels koks nogāzts. Nolauzts. Tātad tikai velns to dara. Nu, un tad es vinu aiztriekšu uz elli. Brālis gan teica - nerausti nu velnu aiz astes, noskaitūsies! Nu, un tā arī pa dal̦ai bija.

Drīz vien brāḷa brīdinājums piepildās kad stāstītājs peldējies ierastajā vietā dzirnavu dīḳ̄, izrādījies, ka tur ūdens negaidīti pacēlies augstāk. Sācis slīkt. Labi, ka brālis izglābis, citādi velnīt's bütu parāvis mani.

Velna brīdinājums sadzirdēts vēl citā epizodē. Tad viņš, jau mežsargs būdams, netālu no mājām krauj kaudzē sazāgêtto malku, lai vēlāk to ar zirgu aizvestu mājās. Un bija liels vējšs. Es tā apskatos, nē, te apkārt ir visi tādi skaisti veseli koki, tur man nekādas briesmas

\footnotetext{
13 Bela 2007, 20.
} 
nedraud. Nesu tik tālāk savus balkus, tos klucēnus. Uzreiz tik dzirdu, ka-krakš! - un reizē ar to krakši arī-bliukš! Liels bērzs, augsts, un pārlūst uz pusēm. Viņu kā ar sviešanu uzsvieda tieši uz maniem tiem klučiem virsū. Ja es būtu tur pakavējies, teiksim, divas, nu, vienu minūti ilgāk, es būtu nosists. Un tad domāju atkal rausti nu velnu aiz astes!

Stāstītājs kā mežsargs saskaras ar to, ka mežs tiek kopts, lolots, ir it kā piejaucēts. No otras puses, mežsargs nevar noliegt, ka mežs ir varens un līdz galam neizzināms. Jums ar to velnu bija jācīnās? - Jāa, ar to velnu. Bet nu padomājiet - tādus skaistus kokus n,em un gāž laukā.

Uz ainavas izjūtu iedarbojas gan tās fiziskā pieredze, gan konkrētā cilvēka biogrāfija, gan simboliskie rāmji, kādos esam raduši uzlūkot un runāt par ainavu. ${ }^{14}$ E. Brieža mūžs saistījies ar mežu, un vina dzīvesstāstu caurvij meža tēma. Bērnības atmiṇās atklājas tēva stāsti, kur mežs liekas kā pasaku valstība. Sirds iesāpas par malumednieka sašauto stirniņu, un dzimst apņēmība - izaugšu liels un pret to cīnīšos. Savukārt mežsarga stāsti par malumedniekiem parāda gan autora profesionālo izveicību, drosmi un spēku, gan laba stāstnieka spējas, gan viņa īpašo, dziḷo attieksmi pret dabu vispār. E. Brieža stāstījumā klausītājs mežu uztver kā skaistu, nedaudz teiksmainu vietu, kur stāstos līdzās cilvēkiem dz̄ivo un darbojas arī pats mežs un tā iemītnieki - stirniņa, lapsa, vanags; darbojas arī negatīvie tēli, velns un malumednieki.

\section{Nobeiguma piezīmes. Mežinieku padoms}

Mutvārdu vēsture un dzīvesstāsti dod iespēju iejusties otra cilvēka dzīves pieredzē, personības izpausmēs, vērojumos, vērtībās un motivācijās un tuvoties tām. Izziņas procesu var virzìt arī praktiskā gultnē, kā to dara meža vēstures pētnieki, tie, kas apgūst nozares profesionāḷu pieredzi. Mutvārdu liecības var sniegt padomus, kā labāk veikt meža apsaimniekošanas darbus, kādā laikā koki noteiktam

${ }^{14}$ Skultans 2007, 222. nolūkam cērtami, uzzināt, kādas metodes un pañēmieni izmantoti agrāk, u. tml. ${ }^{15}$

Bijušie meža darbinieki savā aktīvajā mūžā pieredzējuši dažādas varas maiņas, dažādus saimniekošanas paṇēmienus. Vinu sniegtās atziṇas varētu būt vērā ņemams padomu uzkrājums arī mūsdienās. Jo sevišķi tagad, kad ir atjaunotas agrākās meža īpašuma tiesības. Viena no tēmām, kas aplūkota mutvārdu vēstures intervijās ar mežsaimniekiem, ir tēma par atškirīgo vērtējumu, kas atklājas salīdzinājumos "agrāk un tagad".

Ernests Briedis: Es jau bērnības dienās, es jau biju paredzējis, ka es to mežu saudzē$\check{s} u$. Jo nebija jau tā kā tagad-ielaid cilvēku mežā, cērt, ko gribi, un dari, ko gribi. Viṇš norāda, ka īpaši patīk izkopts mežs: Bet nu jau tādus gan neredz vairs.

Arī ilggadēja mežsarga un Dundagas kokaudzētavas vadītāja Viḷna Mitlera vectēvs no mātes puses bijis mežsargs. Vectēva stādītā ozolu birzs augot vēl joprojām, to novērtējušas vēlākās paaudzes. Tādēḷ viņšs stāstā atsaucas uz tēva padomu, ka mežs jāsaudzē nākamo paaudžu vārdā: Têvs savā mežā necirta mal$k u$, neko. Izñemot, ja vajadzēja pḷavu tīrìt vai grāvjus. Tēvs man teica tā: "Dēlin, mežu tu taupi, mežu tu sargāa. Mežs ir vairāk kā banka. Tu redzi - priekš kara tam bija nauda bankā un tam bija nauda bankā. Izputēja visi. Mežu tu vari paņemt, kad ūdens smel̦as mutē. Tur viņš ir jebkurā laikā." Bija kara laiki, bija kolhoza laiki, un tas mežs vēl šodien stāv. Un tagad ko dara ar mūsu Latvijas mežiem? Mēs šodien nocērtam mežu, kuru izjutīs bērni un bērnu bērni.

Tēma par mežu kā mantojumu, kas jāsargā un jānodod tālāk nākamajām paaudzēm, atklājas arī Jura un Guntas Lapkašu stāstā: Mežs taču aug lēni. Tagad mēs visu pañemsim, un kas tad paliks mūsu bērniem, mazbērniem?

15 Piem., sk. Gimmi, Bürgi 2007. Lai rekonstruètu tradicionālu mežu apsaimniekošanas veidu, tika apvienoti dokumentālie avoti un mutvārdu vēstures intervijas ar bijušajiem darbiniekiem, kuri bija praktizējuši agrākās apsaimniekošanas metodes. Divu pieeju apvienošana l̦āva izvērtēt iepriekšējo periodu mežu izmantošanas praksi no dažādām perspektīvām un rekonstruēt to. 
Uzklausītajos dzīvesstāstos mežs atklājas kā cilvēka darba rezultāta rādītājs un saimnieciskās darbības pamats, taču šiem stāstiem raksturīgs arī prieks par meža skaistumu, par darba izdošanos. Vilnis Mitlers trāpīgi pasaka: Mežs nav kāpostgalva - šodien iestādi, rītdien ñem nost. Skaists mežs intervēto meža darbinieku stāstos ir cilvēka kopts mežs, paša stādīts un aprūpēts, tiek uzsvērta meža vērtība nākamajām paaudzēm. Mežs šajos stāstos ir arī ekonomiska kategorija, tomēr tas nav tikai naudas devējs. Pats mežs ir kā vērtība, kas jāatstāj nākamajām paaudzēm. Un tā nav tikai naudas vērtība (lai gan stāstos atklājas atzinība un prieks par veiksmīgu saimniekošanu). Pieredzējušo meža darbinieku atminuu stāstos pārliecinoša ir meža garīgā vērtỉba, skaistums un prieks, ko tas spēj sniegt cilvēka sirdij.

Raksts tapis Latvijas Zinātnes padomes fundamentālo un lietišḳo pētījumu projekta Nr. 1zp-2018/1-0458 Atminu pārnese starp paaudzèm: naratīvā perspektīva un LU projekta Kritiskā domāšana, inovācija, konkurētspēja un globalizācija (AAP2016/B033) ietvaros.

\section{VĒRES}

Bela, B. (2007) Stāsta dzīve valodā: naratīvās stratēǵijas Latvijas un trimdas dzīvesstāstos. Zirnīte, M. (sast.) Dzīvesstāsti: vēsture, kultūra, sabiedrība. Rīga : LU FSI, 15-33.

Dzīvesstāstu intervijas no Latvijas Nacionālās mutvārdu vēstures krājuma: NMV-226, NMV-322, NMV3167, NMV-4689.

Gimmi, U.; Bürgi, M. (2007) Using Oral History and Forest Management Plans to Reconstruct Traditional Non-Timber Forest Uses in the Swiss Rhone Valley (Valais) Since the Late Nineteenth Century. Environment and History, 13, 2, 211-246.

Milts, A. (2001) Tautas izzina mutvārdu vēsturē. Zirnīte, M. (sast., red.) Spogulis: Latvijas mutvārdu vēsture. Rīga : LU FSI, 33-39.

Portelli, A. (1998) What makes oral history different? Perks, R.; Thomson, A. (eds.) The Oral History Reader. Routledge, 63-75.

Skultans, V. (2005) The Testimony of Lives: Narrative and memory in post-Soviet Latvia. New York : Routledge.

Skultans, V. (2007) Narratives of Landscape in Latvian History and Memory. Empathy and Healing: Essays in Medical and Narrative Anthropology. Berghahn Books, 205-223. 